\title{
RELATIONSHIP BETWEEN FIRM VALUATION, BUSINESS PRACTICES AND EARNINGS MANAGEMENT: A META-ANALYSIS
}

\author{
Ajay Ranjitha ${ }^{1}$ and $R$ Madhumathi ${ }^{2}$ \\ ${ }^{1}$ Indian Institute of Technology, India \\ E-mail: ranjithaajay07@gmail.com \\ ${ }^{2}$ Indian Institute of Technology, India
}

\begin{abstract}
The objective of this paper is to meta-analyze the result of relevant literature capturing the relationship measured in terms of correlation coefficient between valuation and earnings management; business practices (corporate governance) and earnings management; select business practices (financial constraints, credit quality, diversification strategy, product market compeition) and earnings management. We examined 30 empirical studies for the period 2006 to 2015 reflecting 53 correlations among the variables. The result indicates that corporate governance measured using governance index, audit opinion, institutional ownership, family ownership, promoter ownership, dual share, board size, CEO duality and board index have a significant negative relationship with earnings management. This signifies that an effective governance mechanism reduces the extent of earnings management in the firm. The moderator analysis confirmed that the result is similar across different measures of earnings management. In addition, select business practices (product market competition, financial constraints, credit ratings, diversification strategy) show a significant negative relationship with earnings management.
\end{abstract}

Keywords: earnings management, firm valuation, business practices, meta-analysis

ARTICLE INFO

Article History:

Received: 2 December 2018

Accepted: 2 April 2019

Published: 30 April 2019 


\section{INTRODUCTION}

The reliability and accuracy of disclosed financial statements directly affects the decision quality and value creation at all levels. However, decision makers raise concern on the content of financial statements, timeliness of financial reporting and the discretion and judgment of managerial choice of accounting method that creates opportunity for earnings management. Courteau et al. (2015) emphasize on the pitfalls of taking managed earnings at face value for firm valuation that leads to undesirable investment decisions and misallocation of resources. Higher quality of financial information reduces information asymmetry and cost of capital that increases firm valuation (Bushman \& Smith, 2001; Easley \& O’Hara, 2004).

Managerial judgments influence the content of financial information without the intension to distort the reporting quality of firms (Yaping, 2006). This justifies earnings management within limits, however if practiced aggressively may lead to fraud and question the credibility of the firm (Ziv, 1998). Accrual manipulation (Jones, 1991; Dechow et al., 1995, Dechow \& Dichev, 2002; Francis et al., 2004) and real earnings management (Roychowdhury, 2006, Ge \& Kim, 2014, Gunny, 2010) have been extensively investigated in literature as a method of earnings management. Accruals are managerial estimates of future cash flow and hence subject to measurement error and potential manipulation (Rountree et al., 2008). Changes in firm's operational activities such as giving price discounts, reduction of discretionary expenditure and overproduction to manage current period earnings lead to real earnings management (Ge \& Kim, 2014). Earnings smoothing is a form of accruals management that managers indulge in to reduce the variability of income streams (Gao \& Zhang, 2015).

Business practices either motivate or mitigate the extent of earnings management activities. The impact of signficant business practices such as corporate governance, corporate social responsibility, diversification strategy, product market competition and merger activities on earnings management is explored in empirical literature. Business practices in a firm lead to the adjustment of current period earnings and subsequent earnings projections with the anticipation of improving firm valuation and market performance. The cause and effect relationship of earnings management with business practices and firm valuation respectively highlights the need 
for exploring the literature to suggest a research model for determining the limits of earnings management.

\section{RELATIONSHIP OF EARNINGS MANAGEMENT WITH BUSINESS PRACTICES AND FIRM VALUATION: LITERATURE REVIEW}

Meta-analytic literature on relationship between specific business practices such as corporate governance (García-Meca \& Sánchez-Ballesta, 2009) and adoption of International Financial Reporting System (IFRS) (Ahmed et al., 2013) confirm the positive association with earnings quality. Besides governance and reporting practices of firm, literature on the impact of other business practices on earnings management and the effect of earnings management on firm valuation are abundant.

\section{Earnings Management and Business Practices}

Governance system is implemented in a firm with an intension to reduce the opportunistic motives of managers or controlling shareholders and to enhance the credibility of financial information. Corporate governance practice is represented using governance index, audit opinion, institutional ownership, family ownership, promoter ownership, dual share, board size, CEO duality and board index. Other business practices such as improving or maintaining the credit ratings to reduce the cost of borrowings, reducing financing constraints, expanding business across market and product lines and firm level competition exuberates or reduces the extent of earnings management.

\section{Governance Practices}

Corporate governance factors such as board characteristics, board size, board meetings, and presence of audit committee is found to significantly influence earnings management (Iqbal \& Strong, 2010, Anagnostopoulou \& Tsekrekos, 2015; Malik, 2015). Majumdar and Nagarajan (1997) notes that governance structure enables monitoring role that maximizes long term value of firm. 
Owners efficiently controls the production and reporting of firm's accounting information (Fan \& Wong, 2002) and thereby plays a role in deciding the financial reporting quality of firm. Concentrated ownership structure (promoter-controlled firms) is found to significantly favor or mitigate earnings management based on entrenchment and alignment effect theory respectively (Sarkar et al., 2013). Gopalan and Jayaraman (2012) found positive association between concentrated ownership and earnings management. Fan and Wong (2002) report that minority shareholders' wealth is usually expropriated using self-dealing transactions and controlling shareholders mask the influence of such activities on reported earnings through earnings management. However, controlling shareholders with higher cash flow and control rights monitor managerial actions to reduce the information risk arising from information asymmetry between managers and shareholders (Wang, 2006 \& Sarkar et al., 2013). Achleitner et al. (2014) empirically show that family firms strategically utilize earnings management activities. Wang (2006) reports that the relationship between family ownership and earnings quality is not linear and thus higher level of family ownership may reduce the extent of accrual management.

Diffused ownership structure characterized by the presence of large institutional investors are found to play an effective monitoring role to reduce earnings management specifically through accruals manipulation and real earnings management (Ajay \& Madhumathi, 2015; Malik, 2015). Institutional investors actively manage their investment and monitor the corporate financial reporting (Velury \& Jenkins, 2006), hence improving the quality of earnings (active monitoring hypothesis). However, institutional investors with focus on short-term returns prefer firms with stable earnings and are more sensitive to current earnings news of the firm. If they perceive that a firm's stock performance is not as per their expectation, they offload their shares in the market and exit from the firm. Managers anticipating such selling pressure, avoid reporting earnings decline through either accrual or real activities management.

Iqbal and Strong (2010) and Anagnostopoulou and Tsekrekos (2015) investigate the effect of governance structure on accrual manipulation around corporate announcements (right issues and firm seeking a buyer) and found that these corporate events motivate managers to engage in earnings manipulation. Firms with better governance board and effective 
board monitoring are found to indulge in real activities management (Ge \& Kim, 2014). In addition, they found that managers substitute accrual management with real earnings management.

The meta-analysis of studies by Ahmed et al. (2013) highlights the significance of adoption of International Financial Reporting System (IFRS) on earnings quality of firms. García-Meca and Sánchez-Ballesta (2009) meta-analyze the association between corporate governance (board structure) and earnings management paying particular attention to accrual management activities captured in terms of discretionary accruals. The entrenchment and alignment hypothesis linking corporate governance and earnings management can be stated as:

H2.1: There is no relationship between governance practices and earnings management.

H2.2: Earnings management measures do not influence the relationship between governance practices and earnings management.

\section{Other Select Business Practices}

Financial constraints resulting from information asymmetry between firm and potential investors influence the future prospects of firm. Higher information asymmetry leads to reduction in debt capacity of firms (Myers, 1984). This induces debt-financing constraints and thereby increasing cost of financing in a firm. Farrell et al. (2014) show that financing constraint motivates firms to manage earnings through accrual management techniques as compared to real activities management. Credit rating agency look for profitability and earnings power of firms. Change in credit rating has an implication on bond and stock valuation of firms. To avoid the undesirable consequences of change in credit rating (specifically downgrade), managers use earnings management to project stable earnings that alters the credit agency's perception of credit risk (Jung et al., 2013). Rating agencies expect higher risk premium from firms that indulge in real activities management (Ge \& Kim, 2014).

Ze-To (2012) reports positive association between business cycle and persistence of accrual component, where firms are found to increase receivables and inventory in both up and down states of economy. 
Balakrishnan and Cohen (2013) found that competition within firms in similar industry helps to discipline managerial actions that reduces the agency cost. However, higher level of competition sometimes exacerbates earnings management through accrual or real operating decisions thus aggravating the problem of agency cost (Laksmana \& Yang, 2014). Firms exposed to higher level of competition compete with each other for external financing. They tend to indulge in earnings management to meet market expectation as the cost of missing earnings target is higher. Corporate growth strategies that involves expansion across economies or diversification across product segments are found to favor or mitigate earnings management activities. EI Mehdi and Seboui (2011) found that higher degree of market diversification motivates firms to indulge in earnings management while product diversification mitigates it. The following hypothesis based on information asymmetry theory is formulated to examine the relationship between select business practices and earnings management:

H2.3: There is no relationship between select business practices and earnings management.

H2.4: Earnings management measures do not influence the relationship of select business practices and earnings management.

\section{Earnings Management and Firm Valuation}

Bowen et al. (1995) and Graham et al. (2005) provide evidence of stakeholder motivation in earnings management. Empirical studies report positive association between earnings management and firm valuation (Jiraporn et al., 2008; Subramanyam, 1996; Gao \& Zhang, 2015; Robin \& $\mathrm{Wu}, 2014)$. Hunt et al. (2000) and Gao and Zhang (2015) show that earnings smoothing through accruals management improves the information content of earnings and is associated with higher firm performance (Jiraporn et al., 2008; Subramanyam, 1996). Investors prefer firms with higher reporting quality as it lowers the information risk (firm specific non-diversifiable risk) and reduces the information asymmetry (Gaio \& Raposo, 2011). Investors demand high-risk premium from holding securities that perceived to have higher informational risk thereby lowering their valuation. Managing real activities is found to significantly reduce future operating performance of the firm (Gunny, 2010; Li, 2010). The reduction in research and expenditure in current period may increase the net income and cash flow in current period; 
however, it may reduce the future cash flow expectations and therefore reduce the firm valuation. Increase in production leads to reduction in production cost, however if sales does not increase as expected it may increase the inventory cost and influence future cash flows (Cupertino et al., 2016). Kim and Sohn (2013) found that real earnings management increases cost of capital and hence reduces firm valuation.

On the contrary, Rountree et al. (2008) empirically show that earnings smoothing does not add value to the firm though investors prefer less fluctuating income. Institutional investors with better expertise in processing firm's financial information tend to detect smooth earnings and discount the persistence of smoother earnings (Rountree et al., 2008). The empirical evidence on the consequences of earnings management on firm valuation is mixed and ambiguous. One line of argument indicates that managers opportunistically engage in earnings management inducing the agency problem while another suggests that earnings management is intended to convey private information to investors and enhances the information content of earnings (Jiraporn et al., 2008). The information asymmetry hypothesis linking firm valuation and earnings management can be stated as follows:

H2.5: There is no relationship between firm valuation and earnings management

H2.6: Earnings management measures do not influence the relationship between firm valuation and earnings management.

\section{RESEARCH METHODOLOGY AND SAMPLE SELECTION FOR META ANALYSIS OF LITERATURE}

\section{Meta-Analytic Technique}

Meta is a Greek prefix meaning "after" or "beyond", hence metaanalysis is referred to as analysis of analysis (Glass, 1976). Meta-analysis statistically aggregates results across literature (Pomeroy et al., 2008) by systematically bringing out commonalities across studies (Rosenthal, 1995). Pomeroy and Thornton (2008) point out that accounting literature has lower proportion of published meta-analysis studies compared to business 
literature. Lipsey and Wilson (2000) suggest meta-analysis focuses on the direction and magnitude of the effects across studies and not statistical significance and calculate observed effect size to estimate the population effect. Meta-analytic research examining the implication of corporate governance on financial reporting quality (Ahmed \& Courtis, 1999; García-Meca \& Ballesta, 2009) is in plenty and there is scarcity of metaanalysis studies investigating the implication of other business practices that significantly influence earnings management activities.

Meta-analytic technique involves examining the correlation coefficient between the variables (Ahmed \& Courtis, 1999; García-Meca \& Ballesta, 2009) $)^{1}$ to calculate the effect size (Hunter \& Schmidt, 1990). Meta-analysis using correlations computes weighted mean of effect size with more weight given to some studies. The assignment of weights to different studies depends on the application of fixed-effect or random-effects model. Fixed effects model assumes underlying effects are the same for all the studies and examines only sampling variation within the studies. Fixed-effect model estimates the population effect using weighted mean to minimize the variance. Weight is computed as the inverse of that study' variance. The assumptions of fixed-effect model is implausible in many systematic reviews. Studies included in the meta analysis are not identical to assume common effect size across studies. This may lead to biased interpretations. This result in different effect sizes underlying different studies. Heterogeneity across studies is addressed using random-effects meta-analysis. Heterogeneity refers to variability among studies in terms of participants, interventions, outcomes and study design. Random-effects model assumes two components of variation in any given study namely true variation in effect sizes and sampling error.

$$
\mathrm{Y}_{\mathrm{i}}=\mu+\varsigma_{\mathrm{i}}+\varepsilon_{\mathrm{i}}
$$

Where, $\mathrm{Y}_{\mathrm{i}}, \mu, \varsigma_{\mathrm{i} \text { and }} \varepsilon_{\mathrm{i}}$ denote observed effect, overall mean, deviation of true effect size of study from overall mean and deviation of observed effect from true effect respectively. To estimate overall mean $(\mu)$ from observed effects (Yi) the weighted mean is computed. A statistical test

1 Comprehensive meta-analysis software is used for meta-analysis. A trial version of the software is accessed for the same. 
for heterogeneity ${ }^{2}$ is analyzed for the given sample using Q-statistics that follows a chi-square disctribution. The significance of Q-statistic indicates rejection of null hypothesis of homogeneity (García-Meca \& Ballesta, 2009) and signifies the presence of heterogeneity across studies. Hence random effect model is used to meta-analyze the literature considering heterogeneity in effect size and sampling error across empirical studies.

\section{Sample}

Meta-analysis data from relevant studies is accessed using computerized or manual searches. Search databases included Google scholar, Science Direct, Jstor, SSRN, Blackwell, Emerald and other journal publications. Different combination of keywords is used to search empirical literature focusing on valuation (Gao \& Zhang, 2015; Wang, 2014; Rountree et al., 2008), corporate governance practice (Tsipouridou \& Spathis, 2014; Anagnostopoulou \& Tsekrekos, 2015) and other select business practices (Ge \& Kim, 2014; Farrell et al., 2014). Examples of keyword search ("earnings management") with any one or a combination of the phrase such as "firm valuation", "corporate governance", "business cycle", "financial crisis", "diversification strategy", "product market competition", and "credit quality". The literature on other select business practices is recent and hence relevant studies for meta-analysis were identified beginning from 2006 to 2016. Correlation coefficient shows the strength of association between continuous variable (Lipsey \& Wilson, 2000) and helps to integrate results of empirical studies (García-Meca \& Ballesta, 2009) to calculate effect size. Search process resulted in 30 empirical studies that reported correlation coefficient (53 effect sizes) between variables of interest.

If $r$ statistics is not reported, the formula given by Rosenthal and DiMatteo (2001) is used to transform other reported statistics such as t-test, Z-test or P-value into $r$ statistics as shown below:

$$
r=t 2 / \sqrt{ } t 2+d f
$$

where $\mathrm{t}=$ reported statistics of $\mathrm{t}$-value, $\mathrm{Z}$-value or P-value, $\mathrm{df}$ is degrees of freedom

2 Higgins (2003) argues that diversity across studies always occurs and hence statistical heterogeneity is envitable. 
A single study may contribute to multiple effect size (correlation coefficient) and a sub sample analysis within the study may use alterative measures of dependent and independent variables. Ahmed et al. (2013) advocate using multiple effects within each study as averaging the effect sizes may underestimate the degree of heterogeneity within the studies.

\section{Summary Statistics of the Sample}

Figure 1 represents the year wise classification of studies considered for Meta-analysis. Correlation coefficients of studies published in the year $2014(38 \%)$ are higher followed by publication in 2015 (20\%), $2008(13 \%)$, 2010 (13\%), 2006 (3\%), 2012 (4\%), 2013 (4\%), and $2016(2 \%)$. There is a higher representation of recent studies in the sample.

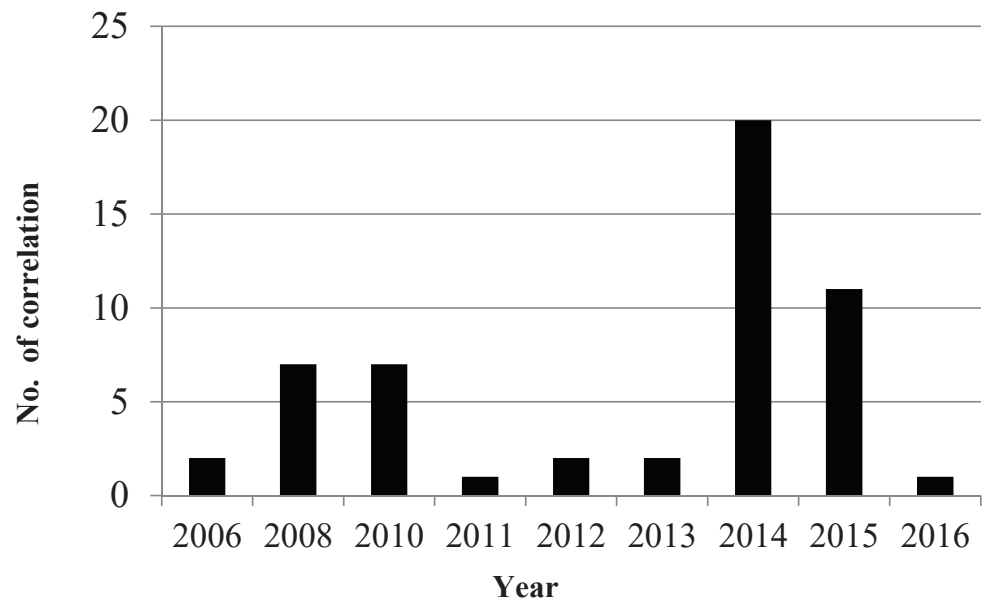

Figure 1: Classification Based on Years

The number of correlation coefficients is higher for studies focusing on discretionary accruals (66\%) followed by real earnings management $(21 \%)$ and then earnings smoothing (13\%) indicating that most of studies examine relationship between discretionary accruals as a measure of earnings management with business practices and firm valuation (Figure 2). 


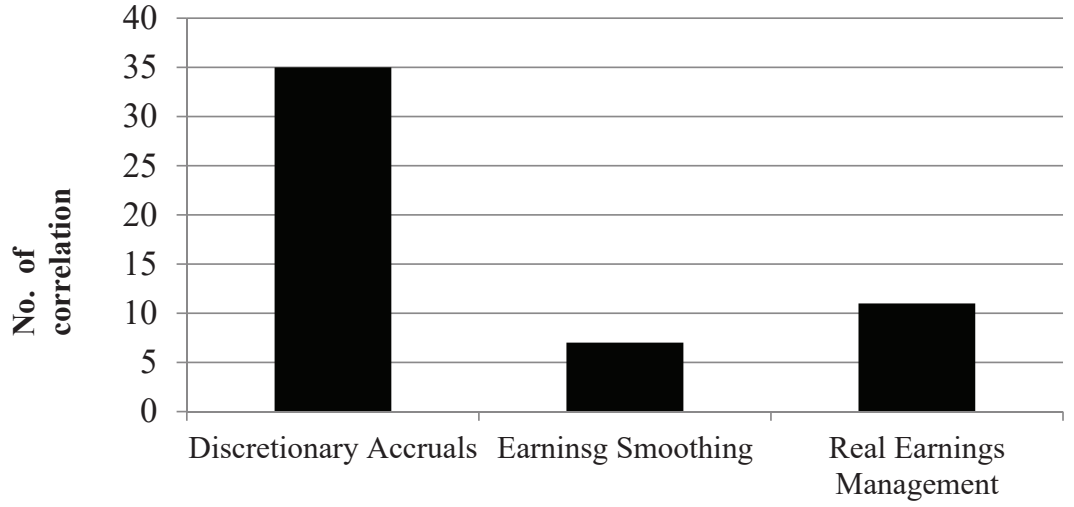

Figure 2: Classification Based on Earnings Management Measures

The number of correlation depicting the studies on the association between firm valuation and earnings management is higher (43\%) followed by studies on corporate governance practices (38\%) and other select business practices (19\%) (Figure 3).

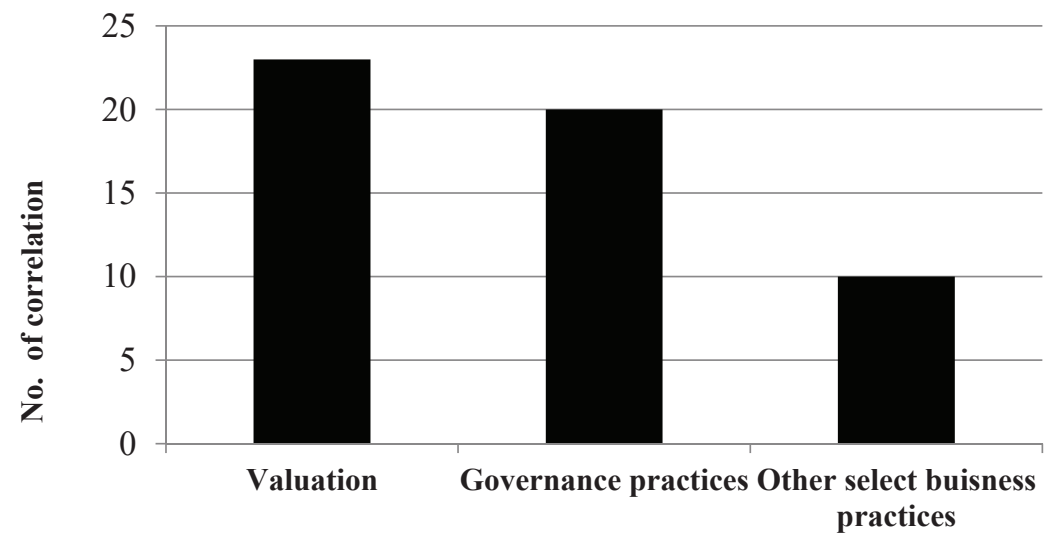

Figure 3: Classification Based on Firm Valuation and Business Practices 


\section{META ANALYSIS}

The random effects model confirmed strong relationships between business practices and earnings management.

\section{Relationship Between Earnings Management and Business Practices}

The average number of observations for studies focucing on governance practices and earnings management is 4249 . Governance practices had a statistically insignificant mean correlation of $-0.008(\mathrm{z}=-$ $2.429, \mathrm{p}<0.05$ ) with earnings management (Table 1). On an average there are 2620 and 9367 number of observations across studies examining the relationship between corporate governance with discretionary accruals and real activities management respectively. Discretionary accruals influence the relationship between earnings management and governance practices (H2.2). This supports the finding of Iqbal and Strong (2010) and Liu and $\mathrm{Lu}$ (2007). Real activity manipulation is found to have negative effect ( $\mathrm{r}$ $=-0.116, \mathrm{z}=-2.223, \mathrm{p}<0.05)$ on governance practices $(\mathrm{H} 2.2)$ confirming the finding of Malik (2015). The presence of independent directors and large number of institutional investors improves monitoring within the firm and constrain the ability of managers to engage in opportunistic real activity manipulation (Malik, 2015). Bushee (1998) argues that higher institutional ownership reduces real earnings management by altering $R \& D$ expenditure

Table 1: Relationship Between Governance Practices and Earnings Management

\begin{tabular}{lcccccc}
\hline Variable & $\mathbf{N}$ & $\mathbf{R}$ & $\begin{array}{c}\text { Mean } \\
\text { correlation }(\mathbf{r})\end{array}$ & Confidence interval & Z-value \\
\hline CG & 4249 & 19 & -0.008 & -0.013 & -0.003 & -3.057 \\
\hline \multicolumn{7}{c}{ Methods of earnings management } \\
\hline DA & 2620 & 14 & $-0.034^{* * *}$ & -0.059 & -0.009 & -2.64 \\
REM & 9367 & 5 & $-0.116^{* *}$ & -0.216 & -0.014 & -2.22 \\
\hline $\begin{array}{l}\text { NOTE: *** and }{ }^{* *} \text { indicates the significance at 1\% and 5\% level respectively, N: Average number of observations, R: Total } \\
\text { number of correlation,CG: Governance practices, DA: Discretionary accruals, REM: Real earnings management }\end{array}$
\end{tabular}


The overall sample examining the relationship between select business practices and earnings management comprises on an average 226246 number of observations. Select buisness practices such as credit rating, financial constraints, business cycle, diversification strategy and product-market competition show a negative relationship with earnings management at $95 \%$ confidence interval $(\mathrm{z}=-3.05$ and $\mathrm{p}=0.01)$ (Table 2$)(\mathrm{H} 2.3)$. Literature focusing specifically on the relationship between select business practices with discretionary accruals and real activities management include on an average 216234 and 48158 number of observations respectively. A significant negative relationship of discretionary accruals $(z=-2.51$, $\mathrm{p}=0.00)$ with select business practices, rejects the null hypothesis $(\mathrm{H} 2.4)$. Competition and diversifying into different business segments and markets improve the disclosure quality of firms $(\mathrm{Li}, 2010)$ and provides incentives for managers to reduce their discretionary behavior with the consequence of reduced agency cost.

Table 2: Relationship Between Other Select Business Practices and Earnings Management

\begin{tabular}{|c|c|c|c|c|c|c|}
\hline Variable & $\mathbf{N}$ & $\mathbf{R}$ & $\begin{array}{c}\text { Mean } \\
\text { correlation (r) }\end{array}$ & \multicolumn{2}{|c|}{ Confidence interval } & \multirow{3}{*}{$\begin{array}{c}\text { Z-value } \\
-3.05\end{array}$} \\
\hline & & & & Lower limit & Upper limit & \\
\hline Select BP & 226246 & 10 & $-0.008^{* * *}$ & -0.013 & -0.003 & \\
\hline \multicolumn{7}{|c|}{ Methods of earnings management } \\
\hline DA & 216234 & 7 & $-0.008^{* *}$ & -0.014 & -0.002 & -2.51 \\
\hline REM & 48158 & 2 & 0.006 & -0.052 & 0.064 & 0.19 \\
\hline
\end{tabular}

\section{Relationship Between Earnings Management and Firm Valuation}

Overall sample examining the relationship between firm valuation and earnings management have on an average 17036 number of observations (Table 3). Further classification of literature indicates that empirical studies focusing on the implication of discretionary accruals and earnings smoothing on firm valuation comprises of 15612 and 14320 number of observations. 
Literature focusing on the association with real earnings management and firm valuation has 25736 number of observations. Meta-analysis concludes that earnings management does not have a significant relationship with firm valuation. Analysis with different measures of earnings management accepts the null hypothesis (H2.6) of no relationship between firm valuation and earnings manipulation using smoothing, discretionary accruals and real earnings management (Allayannis \& Simko, 2009).

Table 3: Relationship Between Firm Valuation and Earnings Management

\begin{tabular}{lcccccc}
\hline Variable & $\mathbf{N}$ & $\mathbf{R}$ & $\begin{array}{c}\text { Mean } \\
\text { correlation }(\mathbf{r})\end{array}$ & Confidence interval & Z-value \\
\hline VALUE & 17036 & 22 & 0.065 & -0.032 & 0.160 & 1.320 \\
\hline DA & 15612 & 13 & 0.091 & -0.039 & 0.218 & 1.370 \\
EM & 14320 & 5 & -0.006 & -0.041 & 0.029 & -0.341 \\
REM & 25736 & 4 & 0.070 & -0.170 & 0.302 & 0.570 \\
\hline
\end{tabular}

NOTE: ${ }^{* * *}$ and ${ }^{* *}$ indicates the significance at $1 \%$ and $5 \%$ level respectively, $N$ : Average number of observations, R: Total number of correlation, VALUE:Firm valuation, DA: Discretionary accruals, REM: Real earnings management

\section{SUMMARY AND LIMITATION}

The systematic review of literature examines the relationship between firm valuation, and select business practices on earnings management. Metaanalysis brings out the significant negative relationship between governance practices and earnings management specifically with discretionary accruals and real earnings management methods. This supports the finding of Velury and Jenkins (2006); Klein (2002); Xi et al. (2003) and Warfield et al. (1995) that better governance structure in a firm constrain the occurrence of earnings management. Sound governance structures limit opportunistic accrual estimation and ensure compliance with mandated financial reporting requirements (Davidson et al., 2005). Effective internal control system enhances the quality of accruals and reduces discretionary accruals within the firm. Internal governance practices also lower real earnings management activities of a firm (Visvanathan, 2008; Kang \& Kim, 2012). 
Meta-analysis on product market competition, financial constraints, credit ratings and diversification strategy proposes a negative relationship with earnings management. Significant negative relationship with accounting-based manipulation using discretionary accruals supports the finding of Jiraporn et al. (2008) that diversified firms have lower level of earnings management. Product market competition is an efficient monitoring and disciplining mechanism that aligns the interest between managers and shareholders. This reduces potential agency problems (Shleifer \& Vishny, 1997 ) and the ability of managers to manage earnings is curtailed.

The number of studies focusing on earnings management using earnings smoothing technique is limited in the present study. Hence, moderating effect analysis could not establish the relationship with earnings smoothing. Future studies could focus on other methods of earnings management such as classification shifting and on corporate events (initial public offer, share buyback) that has an implication on the extent of earnings management.

\section{REFERENCES}

Achleitner, A. K., Günther, N., Kaserer C., \& Siciliano, G. (2014). Real earnings management and accrual-based earnings management in family firms. European Accounting Review, 23(3), 431-461.

Ahmed, K., Chalmers, K. \& Khlif, H. (2013). A meta-analysis of IFRS adoption effects. International Journal of Accounting, 48(2), 173-217

Ajay, R. \& Madhumathi, R. (2015). Do corporate diversification and earnings management practices affect capital structure?. An empirical analysis, Journal of Indian Business Research, 7(4), 360 - 378.

Allayannis, G. \& Simko, P. J. (2009). Earnings smoothing, analyst following, and firm value (Working paper). Retrieved from https://faculty.darden. virginia.edu/AllayannisY/documents/AS-Earni ngs\%20Smoothing\%20 Analyst\%20Following\%20and\%20Firm\%20Value.pdf 
Anagnostopoulou, S. C. \& Tsekrekos, A. E. (2015). Earnings management in firms seeking to be acquired. The British Accounting Review, 47(4), 351-375.

Balakrishnan, K. \& Cohen, D. A. (2013). Competition and financial accounting misreporting (Working paper). Retrieved from https://ssrn. com/abstract $=1927427$

Bowen R., L. DuCharme \& Shores, D. (1995). Stakeholders' implicit claims and accounting method choice. Journal of Accounting and Economics, 20(3), 255-295.

Bushee, B. J. (1998). The influence of institutional investors on myopic R\&D investment Behavior. The Accounting Review, 73, 305-333.

Bushman, R. M. \& Smith, A. J. (2001). Financial accounting information and corporate governance. Journal of Accounting and Economics, $32(1-3), 237-333$.

Davidson, R., J. Goodwin-Stewart \& Kent, P. (2005). Internal governance structures and earnings management. Accounting \& Finance, 45(2), 241-267.

Dechow, P., \& Dichev, I, (2002). The quality of accruals and earnings: The Role of Accrual Estimation Errors, The Accounting Review, 77, 35-59.

Dechow, P., Sloan, R. \& Sweeney, A. (1995). Detecting Earnings management. The Accounting Review, 70(2), 193-225.

EI Mehdi, I. K \& Seboui, S. (2011). Corporate diversification and earnings management. Review of Accounting and Finance, 10, 176-196.

Fan, J. P. H \& Wong, T. J. (2002), Corporate ownership structure and the informativeness of accounting earnings in East Asia. Journal of Accounting and Economics, 33(3), 401-425.

Farrell, K., Unlu, E. \& Yu, J. (2014). Stock repurchases as an earnings management mechanism: The impact of financing constraints. Journal of Corporate Finance, 25, 1-15. 
Francis, J., LaFond, R., Olsson, P. \& Schipper, K. (2004). Costs of equity and earnings attributes. The Accounting Review, 79(4), 967-1010.

Gao, L., \& Zhang, J. H. (2015). Firms' earnings smoothing, corporate social responsibility and valuation. Journal of Corporate Finance, 32, 108-127.

García-Meca, E. \& Sánchez-Ballesta, J. P. (2009). Corporate governance and earnings management: A meta-analysis. Corporate Governance: An International Review, 17(5), 594-610.

Ge, W. \& Kim, J. B. (2014). Boards, takeover protection, and real earnings management. Review of Quantitative Finance and Accounting, 43(4), 651-682.

Glass, G. V. (1976). Primary, secondary, and meta-analysis of research. Educational Researcher, 5(10), 3-8.

Gopalan, R. \& Jayaraman, S. (2012). Private control benefits and earnings management: Evidence from insider controlled firms. Journal of Accounting Research, 50, 117-157.

Graham, J. R., Harvey, C. R. \& Rajgopal, S. (2005). The economic implications of corporate financial reporting. Journal of Accounting and Economics, 40(1-3), 3-73.

Gunny, K. (2010). The relation between earnings management using real activities manipulation and future performance: Evidence from meeting earnings benchmarks. Contemporary Accounting Research, 27(3), $855-888$.

Hunter, J. \& Schmidt, F. (1990). Methods of meta-analysis: Correcting error and bias in research findings. Beverly Hills CA: Sage.

Iqbal, A. \& Strong, N. (2010). The effect of corporate governance on earnings management around UK rights issues. International Journal of Managerial Finance, 6(3), 168-189. 
Jiraporn, P., Kim, Y. S. \& Mathur I. (2008). Does corporate diversification exacerbate or mitigate earnings management? An empirical analysis. International Review of Financial Analysis, 17(5), 1087-1109.

Jung, B., Soderstrom, N. \& Yang, Y. S. (2013). Earnings smoothing activities of firms to manage credit ratings. Contemporary Accounting Research, $30,645-676$.

Kang, S. A. \& Kim Y. S. (2012). Effect of corporate governance on real activity-based earnings management: Evidence from Korea. Journal of Business Economics and Management, 13(1), 29-52.

Kim, J. B. \& Sohn, B. C. (2013). Real earnings management and cost of capital. Journal of Accounting and Public Policy, 32(6), 518-543.

Klein, A. (2002). Audit committee, board of director characteristics, and earnings management. Journal of Accounting and Economics, 33(3), $375-400$.

Laksmana, I. \& Yang, Y. W. (2014). Product market competition and earnings management: Evidence from discretionary accruals and real activity manipulation. Advances in Accounting, Incorporating Advances in International Accounting, 30, 263-275.

Li, X. (2010). The impacts of product market competition on the quantity and quality of voluntary disclosures. Review of Accounting Studies, 15(3), 663-711.

Lipsey, M. W \& Wilson, D. B. (2000). Practical meta-analysis. Thousand Oaks, CA: Sage.

Liu, Q., \& Lu, Z. (2007). Corporate governance and earnings management in the Chinese listed companies: A tunneling perspective. Journal of Corporate Finance, 13(5), 881-906.

Majumdar, S. K. \& Nagarajan, A. (1997). The impact of changing stock ownership patterns in the United States: Theoretical implications and some evidence. Revue d'Économie Industrielle, 82(1), 39-54. 
Malik, M. (2015). Corporate governance and real Earnings management: The role of the board and institutional investors. Journal of Knowledge Globalization, 8(1), 37-87.

Myers, S. C. (1984). The capital structure puzzle. Journal of Finance, 39, 575-592.

Pomeroy, B. \& Thornton, D. B. (2008). Meta-analysis and the accounting literature: The case of audit committee independence and financial reporting quality. European Accounting Review, 17(2), 305-330.

Rosenthal, R. (1995). Writing meta-analytic reviews. Psychological Bulletin, 118(2), 183-192.

Rosenthal, R., \& DiMatteo, M. R. (2001). Meta-analysis: Recent developments in quantitative methods for literature reviews. Annual Review of Psychology, 52, 59-82.

Rountree, B., Weston, J. P. \& Allayannis, G. (2008). Do investors value smooth performance? Journal of Financial Economics, 90(3), 237-251.

Roychowdhury, S. (2006). Earnings management through real activities manipulation. Journal of Accounting and Economics, 42(3), 335-370.

Sarkar, J., Sarkar, S. \& Sen, K. (2013). Insider control, group affiliation and earnings management in emerging economies: Evidence from India (Working paper). Retrieved from http://aicg.org/_res/aicg/etc/ Inside r_Control,_Group_Affiliation_and_Earnings_Management_In_ Emerging_Economies-Evidence_from_India_Kaustav_Sen.pdf

Shleifer, A. \& Vishny, R. (1997). A survey of corporate governance. Journal of Finance, 52(2), 737-783.

Subramanyam, K. R. (1996). The pricing of discretionary accruals. Journal of Accounting and Economics, 22, 249-281.

Tsipouridou, M. \& Spathis, C. (2014). Audit opinion and earnings management: Evidence from Greece. Accounting Forum, 38(1), 38-54. 
Velury, U. \& Jenkins, D. S. (2006). Institutional ownership and the quality of earnings. Journal of Business Research, 59, 1043-1051.

Visvanathan, G. (2008). Corporate governance and real earnings management. Academy of Accounting and Financial Journal, 12(1), $9-22$.

Wang, D. (2006) Founding family ownership and earnings quality. Journal of Accounting Research, 44, 619-656.

Warfield, T. D., Wild, J. J. \& Wild, K. L. (1995). Managerial ownership, accounting choices and informativeness of earnings. Journal of Accounting and Economics, 20, 61-91.

Xie, B., Davidson, N. W. \& DaDalt, P. (2003). Earnings management and corporate governance: The roles of the board and the audit committee. Journal of Corporate Finance, 9(3), 295-316.

Yaping, N. (2006) A different perspective of earnings management. Canadian Social Science, 2(4), 1-7.

Ze-To, S. Y. M. (2012). Earnings management and accrual anomaly across market states and business cycles. Advances in Accounting, incorporating Advances in International Accounting, 28, 344-352.

Ziv, A. (1998) Discussion of earnings management and the revelation principle. Review of Accounting Studies, 3, 35-40. 